\title{
Granitic magmatism related to early Paleozoic continental collision in North Qinling
}

\author{
ZHANG ChengLi ${ }^{1 *}$, LIU Liang ${ }^{1}$, WANG Tao ${ }^{2}$, WANG XiaoXia ${ }^{3}$, LI Lei $^{1,4}$, GONG QiFu $^{1,5} \&$ \\ LI XiaoFei ${ }^{1,4}$
}

${ }^{1}$ State Key Laboratory of Continental Dynamics, Department of Geology, Northwest University, Xi'an 710069, China;

${ }^{2}$ Institute of Geology, Chinese Academy of Geological Sciences, Beijing 100037, China;

${ }^{3}$ Institute of Mineral Resources, Chinese Academy of Geological Sciences, Beijing 100073, China;

${ }^{4}$ Northwest Geological Institute of Nonferrous Metals, Xi'an 710054, China;

${ }^{5}$ No. 203 Research Institute of Nuclear Industry, Xianyang 712000, China

Received June 9, 2013; accepted July 15, 2013; published online August 23, 2013

\begin{abstract}
Zircon U-Pb dating of early Paleozoic granitoids in North Qinling yields three age peaks of 500, 452 and 420 Ma. They can be temporally correlated with high-pressure to ultrahigh-pressure metamorphism at ca. $500 \mathrm{Ma}$, retrograde granulite-facies metamorphisms at ca. $450 \mathrm{Ma}$ and amphibolite-facies metamorphism at ca. $420 \mathrm{Ma}$, respectively. The first episode of granitic magmatism is considered to have resulted from continental collision, whereas the second and third episodes of magmatism are attributed to crustal uplifting. Combined with the regional geological setting and new results from high-pressure and ultrahigh-pressure metamorphic rocks, the ca. 500 Ma magmatism is interpreted as the result of partial melting of sedimentary rocks in accretionary wedge between the south Qinling microcontinent and the north Qinling belt including the southern margin of the North China Craton. The ca. $450 \mathrm{Ma}$ intensive magmatism is ascribed to dehydration melting of deeply subducted continental crust at thickened conditions in response to slab breakoff, and the final magmatism in ca. $420 \mathrm{Ma}$ is interpreted as the product of partial melting during the tectonic transition from contraction to extension.
\end{abstract}

U-Pb dating, granitoids, high-pressure to ultrahigh-pressure, tectonic evolution, North Qinling

Citation: $\quad$ Zhang C L, Liu L, Wang T, et al. Granitic magmatism related to early Paleozoic continental collision in North Qinling. Chin Sci Bull, 2013, 58: 44054410, doi: 10.1007/s11434-013-6064-z

The Qinling orogen is located between the North China Block (NCB) and South China Block (SCB), and is linked with the Tongbai-Dabie orogens to the east and the Qilian-Kunlun orogens to the west. It serves as an important part of the Central Orogenic Belt of China. Since the 1980s, many geologists have been involved in the study of the tectonic evolution of the Qinling orogen, and numerous results have been obtained. The Qinling orogen is regarded as a composite orogen that experienced multiple tectonic development. The final collision between the NCB and SCB occurred in the early Mesozoic along the Mianlue suture zone [1-3], shaping its present tectonic framework (Figure 1) that is comprised of the north Qinling belt (NQB, included the

*Corresponding author (email: clzhang@nwu.edu.cn) southern margin of the NCB), south Qinling belt (SQB) and the northern margin of the SCB separated by the Shangdan suture zone (SDSZ) and Mianlue suture zone (MLSZ), respectively. However, the early tectonic evolution of the Qinling orogen is poorly constrained, such as the timing of subduction of Paleozoic oceanic crust and subsequent collisional process for the closure of Paleotethys. Advances have been made in the understanding of time-space distribution and the nature of HP-UHP metamorphism in the NQB [4-15] after two-decade consistent studies, demonstrating that the early Paleozoic HP-UHP metamorphism was the consequence of northward continental deep-subduction along the SDSZ [16]. The new results concerning the early Paleozoic HP-UHP metamorphism shed some new light on the process and age of subduction of the oceanic crust as 


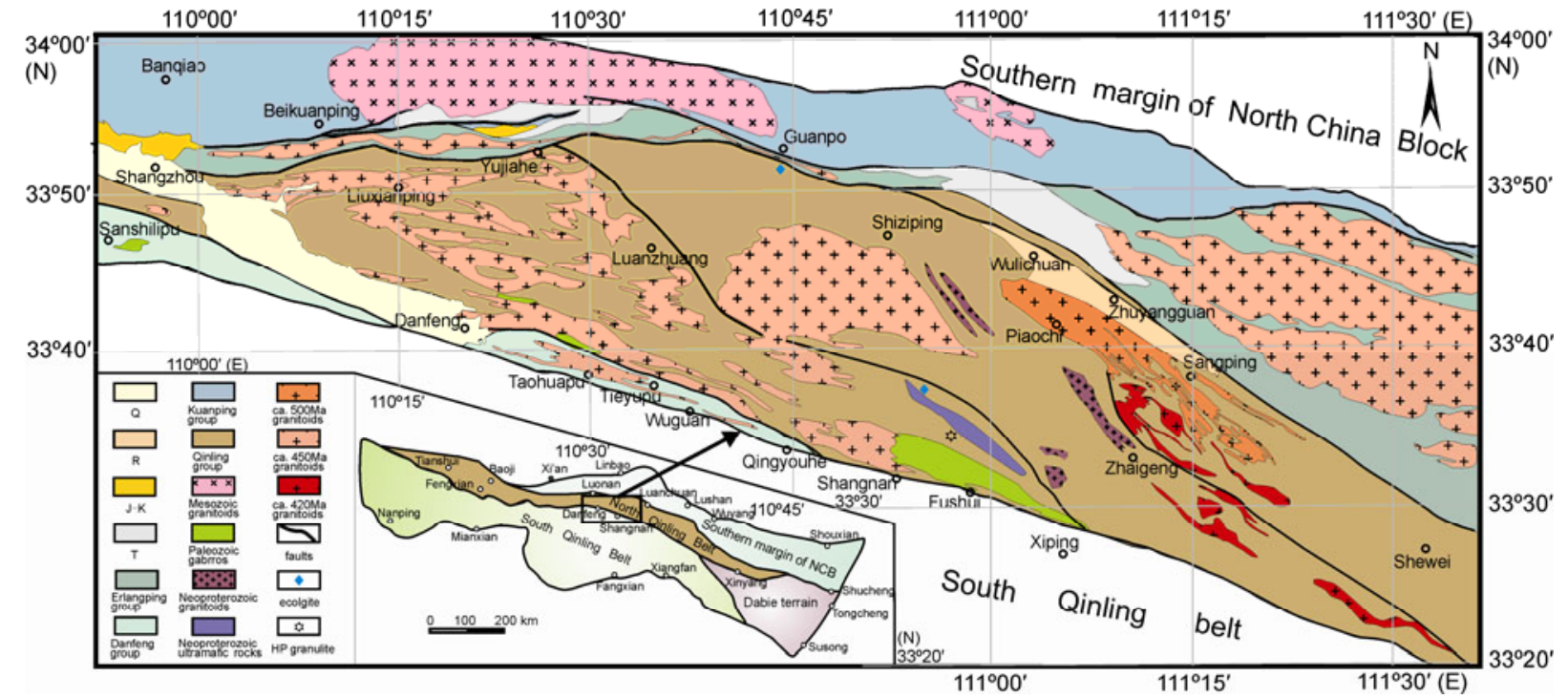

Figure 1 Sketch geological map of the Shangzhou-Danfeng areas in NQB

well as amalgamation among continental blocks during the early Paleozoic in the Qinling orogen.

The oceanic/continental subduction and continental collision could result in HP-UHP metamorphism, and the subducted slab may be exhumed due to its detachment in subduction channel and slab breakoff in the transitional zone between ocean and crust $[17,18]$. Granitic magmatism in the subducting, collisional and post-collisional processes would occur owing to dehydration and thermal change of subducted and exhumed slabs in progressive and retrogressive metamorphism $[19,20]$. As a result, different tectonic stage and origin of granitoids in continental orogen can be used to constrain the processes and closing time of oceanic basins, continental collision and exhumation. We thus carried out a comprehensive study of some granitoid plutons adjacent to HP-UHP rocks in the NQB. We also make a discussion about possible relationship of early Paleozoic collision and subsequent granitic magmatism in the NQB in consideration of some new results of HP-UHP metamorphism, and try to reconstruct early Paleozoic tectonic history in the Qinling orogen.

\section{Geological setting}

The NQB, bounded on the north by the Luonan-Luanchuan fault and on the south by the SDSZ, consists of four units, the Kuanping, Erlangping, Qinling and Danfeng groups from north to south, extending more than one thousand kilometers from east to west. The Kuanping Group displays an association of greenschists, mica-quartz schists and quartz-rich marbles, and yields young concordant detrital zircon ages of 550-450 Ma from meta-sandstones, confirming that they were formed in a period from the late Neoproterozoic to the early Paleozoic [21]. To the south of the Kuanping group occurs the Erlangping Group, which is dominated by greenschist- to amphibolite-facies backarcbasin volcanics associated with some sedimentary rocks. The Erlangping Group is intruded by $490-480$ Ma granitoids [22], suggesting that it should have been formed before 490 Ma. The Qinling Group occurs as lenticular bodies scattering in the middle of the NQB, and consists mainly of biotite-plagioclase and garnet-sillimanite gneisses, micaquartz schists, graphite marbles and minor amphibolites. Detrital zircons from the Qinling Group gives ages from 1500 to1900 Ma [21,23] and gneissic granitoids are dated at $950 \mathrm{Ma}$ [24]. These facts indicate that their protoliths were formed in the early Neoproterozoic. The Danfeng Group crops out in the southern NQB, and is composed of arc volcanic-sedimentary rocks that underwent greenschist to low amphibolite facies metamorphism and is intruded by the 517-430 Ma gabbroic intrusion [25]. Their youngest concordant detrital zircon age is $827 \mathrm{Ma}$, suggesting that the Danfeng Group was deposited after 827 Ma [21], most possibly during 827-517 Ma. It is also striking that there exist many early Paleozoic granitoid plutons [26] and anatectic veins in the NQB. A number of HP-UHP rocks have been identified in the boundary areas between the Shaanxi and Henan provinces, with the metamorphic peak ages of ca. $500 \mathrm{Ma}[16]$. All the data imply that the NQB should be an important tectonic belt formed from the Neoproterozoic to early Paleozoic.

\section{Early Paleozoic granitoid intrusions in the NQB}

Early Paleozoic granitic plutons in NQB widely occur in the areas of Danfeng County in Shaanxi Province and Xixia County in Henan Province (Figure 1). The granitoids can be subdivided into three types according to their field features.

(1) Gneissic granitoid plutons. The Piaochi pluton or 
batholith is a proxy of this type, which intrudes into the Qinling Group, and crops out in an area north of Piaochi village in Xixia County of Henan Province. This pluton experienced strong deformation with its gneissic structure parallel to regional foliation. It consists of medium- to coarse-grained monzogranites with mineral assemblage of K-feldspar $(\sim 35 \%)$, plagioclase $(\sim 30 \%)$, quartz $(\sim 25 \%)$, biotite $(\sim 15 \%)$ and minor hornblende $(\sim 3 \%)$. The pluton yields a formation age of $496.1 \pm 4.2 \mathrm{Ma}$, consistent with the age of $495 \pm 6$ Ma obtained by Wang et al. [26]. Furthermore, two anatectic granitic veins in the Qinling Group to the southern Piaochi village of Xixia County and Yongyu of Danfen County of Shaanxi Province gives weighted mean ${ }^{206} \mathrm{~Pb} /{ }^{238} \mathrm{U}$ ages of $501.2 \pm 4.2 \mathrm{Ma}$ and $501.4 \pm 8.1 \mathrm{Ma}$, respectively, which are interpreted as formation ages similar to the ages of $500 \mathrm{Ma}$ [27] and 497 $\pm 12 \mathrm{Ma}$ [24] from granitic veins in the NQB. They are texturally and compositionally similar to gneissic batholith, implying that both were formed in the same magmatic event. The gneissic granitoids and anatectic veins obviously represent an earliest event of magmatism caused by the crustal partial melting and granitic intrusion in the NQB during early Paleozoic.

(2) Granitic plutons with weak gneissic structures. These granitic plutons are widely present in the Qinling, Erlangping and Danfeng groups. Some plutons, such as the Liuxianping, Kuanping, Zaoyuan, Huichizi, Shangnan and Sikeshu plutons, show weak gneissic to massive structures and medium- to coarse-grained textures. They are composed mainly of monzogranites, granodiorites and some biotitegranites with mineral assemblages of K-feldspars (25\%$40 \%$ ), plagioclases $(30 \%-35 \%)$, quartz $(25 \%-30 \%)$, amphibolite $(8 \%-15 \%)$, biotites $(5 \%-10 \%)$ and minor opaque oxides. The Liuxianping pluton is dated at $456.1 \pm 1.9 \mathrm{Ma}$, the Kuanping pluton at $452.8 \pm 2.0 \mathrm{Ma}$, and the Zaoyuan pluton at $456.1 \pm 1.9 \mathrm{Ma}$, the Huichizi plutons at $445.6 \pm 6.1$ $\mathrm{Ma}$, and the Sikeshu pluton at 464.1 $\pm 4.6-468.5 \pm 4.1 \mathrm{Ma}$, respectively [22]. In addition, garnet-bearing mica-granitic plutons, like the Huangbaicha and Shangmashi plutons, intrude into the northern part of the Qinling Group, with their ages varying from $447.8 \pm 2.5 \mathrm{Ma}$ to $445.7 \pm 5.3 \mathrm{Ma}$. They have mineral assemblages of K-feldspars ( 40\%), plagioclases $(\sim 20 \%)$, quartz $(\sim 30 \%)$, muscovites $(\sim 8 \%)$ and minor biotites $(\sim 5 \%)$ and garnet $(\sim 5 \%)$. Furthermore, coeval Ziyu gabbroic pluton intruded into the Danfeng meta-volcanic-sedimentary sequence. This gabbroic pluton obtained the formation age of $432.2 \pm 2.3 \mathrm{Ma}$. The Lajimiao and Sifangtai gabbroic plutons intruding the Danfeng Group also yield the forming ages of $422 \pm 7 \mathrm{Ma}$ and $460 \pm 29 \mathrm{Ma}$ $[28,29]$. Together with Lajimiao and Sifangtai gabbroic plutons, the Ziyu gabbroic pluton was representative of early Paleozoic basic magmatism. Thus, the crust-derived and mantle-derived magmas occurred around $450 \mathrm{Ma}$, indicating a strong thermo-tectonic magmatic event during early Paleozoic.

(3) Undeformed massive leucogranite plutons. They ap- pear as undeformed smaller granitic bodies or veins intruding the Piaochi pluton and Qinling Group, and consist chiefly of medium-grained muscovite granites. Their mineral assemblages are K-feldspar $(\sim 40 \%)$, plagioclase $(\sim 20 \%)$, quartz $(\sim 30 \%)$, muscovite $(\sim 8 \%)$ and minor garnet $(\sim 5 \%)$. The Anjiping pluton yields a weighted mean ${ }^{206} \mathrm{~Pb} /{ }^{238} \mathrm{U}$ age of $416.7 \pm 1.8 \mathrm{Ma}$, and a granitic vein in the Piaochi pluton gives a similar age of $411.7 \pm 3.7 \mathrm{Ma}$. These ages are interpreted as forming ages and imply the latest granitic magmatism event during early Paleozoic.

\section{Granitic magmatism in response to tectonic events}

Previous studies on the NQB tectonics proposed that the Qinling oceanic crust began northward subduction in early Paleozoic, and the NQB then developed as an active continental margin characterized by development of a trencharc-basin system. The oceanic crust was consumed around the middle Paleozoic, with remnant sea basins persisting into the Carboniferous [1,3,30,31]. Supported by new data of high-quality geochronology and results, it is suggested that that the subduction of the Qinling oceanic crust might have started as early as $600 \mathrm{Ma}$, and lasted until $520 \mathrm{Ma}$ [21]. Several episodes of arc-continental collision might have taken place in the process of early Paleozoic convergence between the NCB and SCB. The Qinling oceanic crust was completely consumed alone the SDSZ in the Devonian $[1,13,25,32,33]$. The HP-UHP metamorphism with the peak age of $500 \mathrm{Ma}$ and two-phase retrogressive metamorphism of $450 \mathrm{Ma}$ granulite- and $420 \mathrm{Ma}$ amphibolitefacies, were distinguished in the NQB. The HP-UHP rocks are interpreted as the products of deep continental subduction, whereas two separate uplift events might be responsible for the two-phase retrogressive metamorphism [14-16]. Obviously, the three stages of granitic magmatism with the ages of 500, 450 and 420 Ma (Figure 2) are consistent with

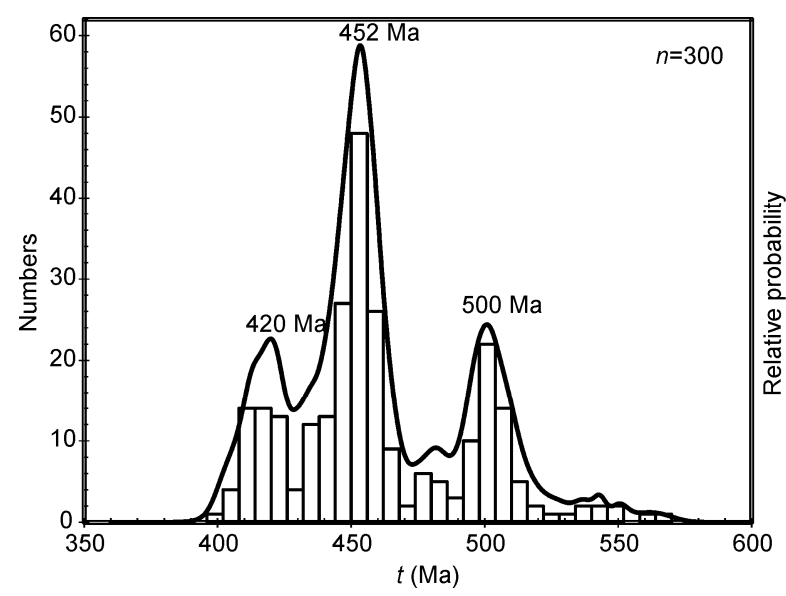

Figure 2 Histogram of zircon $\mathrm{U}-\mathrm{Pb}$ ages for the granitoids in NQB. 
the HP-UHP peak metamorphism and the two-phase retrogressive metamorphism, and their occurrences might be attributed to closure of Qinling ocean basin, the collision between $\mathrm{NCB}$ and $\mathrm{SQB}$, and the related thermotectonic magma events.

The first-stage ( 500 Ma) granitic magmatism was contemporaneous with the ca. 500 Ma HP-UHP metamorphism [16]. Considering that the granitic pluton and coeval anatectic veins were strongly deformed, the granitic magmatism might have resulted from crustal partial melting under the compressive environment. The plutons are geochemically similar to S-type granitoids with high contents of $\mathrm{SiO}_{2}$ $(71.01 \%-71.62 \%), \quad \mathrm{K}_{2} \mathrm{O}+\mathrm{Na}_{2} \mathrm{O} \quad(8.14 \%-8.43 \%), \quad \mathrm{Al}_{2} \mathrm{O}_{3}$ $(15.41 \%-15.73 \%)$ and low $\mathrm{CaO}(1.56 \%-1.91 \%), \mathrm{MgO}$ $\left(0.48 \%-0.73 \% ; \mathrm{Mg}^{\#}=43.19-48.01\right)$. Their A/CNK values range from 1.05 to 1.09 , indicating peraluminous and calc-alkaline series. They are characterized by high LREE and LILE, moderate negative Eu anomalies, poor HFSE and depletion of $\mathrm{Nb}$, Ta, Sr, Ti and P. The initial ${ }^{87} \mathrm{Sr} /{ }^{86} \mathrm{Sr}$ ratios are very high, ranging from 0.72123 to 0.72710 . They, however, have very low $\varepsilon_{\mathrm{Nd}}(t)$ of -10.6 to -9.3 (Figure 3 ). The two-stage model ages $\left(T_{\mathrm{DM} 2}\right)$ of the Piaochi monzogranite are from 1.82 to $2.15 \mathrm{Ga}$. The Piaochi pluton and anatectic veins have negative zircon $\varepsilon_{\mathrm{Hf}}(t)$ values -27.54 to -6.21 for the Piaochi pluton and -17.05 to -0.53 for the anatectic veins (Figure 3 ). The $T_{\mathrm{DM} 2}$ ranges from 1.59 to $2.66 \mathrm{Ga}$ for the Piaochi pluton and from 1.25 to 2.14 $\mathrm{Ga}$, respectively. In addition, there occur many inherited zircons in the Piaochi pluton and anatectic veins with age range from 2.5 to $0.60 \mathrm{Ga}$. All isotopic compositions mentioned above suggest that they are predominantly derived from Mesoproterozoic crust, similar to the Qinling paragneisses. Interestingly, the inherited zircons with the ages from 850 to $650 \mathrm{Ma}$ are not present in paragneisses of the Qinling Group, although the inherited zircons of 2.5-1.0 Ga is coherent with Paleo-Mesoproterozoic peak of detrital zircons from the Qinling Group [21]. The 850-650 Ma ages were recently reported in the SQB and the northern margin of the SCB [34-37], implying that they came partially from the SQB basement besides paragneisses from the Qinling
Group. It is likely that the plutons originated mainly from partial melting of clastic rocks from the NQB, with some addition of the SQB materials due to the northward subduction of the SQB beneath the NQB including the southern margin of the NCB around $500 \mathrm{Ma}$. The above data can thus account for the simultaneousness of granitic magmatism the HP-UHP metamorphism in the NQB.

The second-stage ( $450 \mathrm{Ma})$ granitic magmatism extensively intrude into different units of the NQB, and occurred simultaneously with granulite retrogressive metamorphism as a result of the first-phase uplifting [16]. The granitic plutons are fairly deformed and composed mainly of I-type granodiorites, monzogranites and minor garnet-bearing mica granites. Monzogranite and granodiorite have variable $\mathrm{SiO}_{2}\left(\mathrm{SiO}_{2}=64.31 \%-75.32 \%\right)$, high $\mathrm{K}_{2} \mathrm{O}+\mathrm{Na}_{2} \mathrm{O}$ (6.01\%$10.45 \%), \mathrm{Al}_{2} \mathrm{O}_{3}(13.67 \%-17.87 \% ; \mathrm{A} / \mathrm{CNK}=1.01-1.17)$ and high $\mathrm{Na}_{2} \mathrm{O}\left(\mathrm{Na}_{2} \mathrm{O} / \mathrm{K}_{2} \mathrm{O}=0.48-3.89\right)$, low $\mathrm{FeO}^{\mathrm{T}}(0.34 \%-$ $3.88 \%)$ and $\mathrm{MgO}\left(0.09 \%-1.39 \% ; \mathrm{Mg}^{\#}=25.69-52.17\right)$. They are obviously calc-alkaline to high-K calc-alkaline and peraluminous, characterized by low to moderate fractionation of LREE and HREE and moderate negative to positive $\mathrm{Eu}$ anomalies $\left(\mathrm{Eu} / \mathrm{Eu}^{*}=0.48-1.47\right)$. They are also enriched in LILEs and depleted in HFSEs with pronounced negative spikes of $\mathrm{Nb}$, Ta, Ti and $\mathrm{P}$. The initial ${ }^{87} \mathrm{Sr} /{ }^{86} \mathrm{Sr}$ ratios are moderate to high, ranging from 0.70237 to 0.70972 . The $\varepsilon_{\mathrm{Nd}}(t)$ values vary from -6.26 to 0.21 (Figure 3 ) and and $T_{\mathrm{DM} 2}$ from 1.17 to $1.20 \mathrm{Ga}$, respectively. The zircon $\varepsilon_{\mathrm{Hf}}(t)$ values are from -11.7 to 8.6 (Figure 3 ) and $T_{\mathrm{DM} 2}$ ages from 0.84 to $2.56 \mathrm{Ga}$, suggesting a mixed source from mantle and crust materials, which is similar to those of first-stage granitoids. The coeval gabbros display a constant $\mathrm{Si}_{2} \mathrm{O}(48.16 \%-48.66 \%)$, low $\mathrm{K}_{2} \mathrm{O}(0.22 \%-0.27 \%)$ and high $\mathrm{Na}_{2} \mathrm{O}(2.29 \%-2.81 \%), \mathrm{FeO}^{\mathrm{T}}(6.53 \%-7.60 \%)$ and $\mathrm{MgO}$ $(9.12 \%-9.74 \%)$. Geochemically, the gabbros have an affinity of mantle-derived magma in subduction zones, showing a flat REE pattern, relative enrichment of LILEs and evidently positive $\mathrm{Pb}$ anomaly and depletion of $\mathrm{Nb}$ and $\mathrm{Ta}$. They have low $\left({ }^{87} \mathrm{Sr} /{ }^{86} \mathrm{Sr}\right)_{\mathrm{i}}$ ratios of 0.70353 to 0.70434 and positive $\varepsilon_{\mathrm{Nd}}(t)$ values of 3.98 to 4.10 . The zircon $\varepsilon_{\mathrm{Hf}}(t)$ values are variable from -23.7 to 9.6 (Figure 3), indicating the
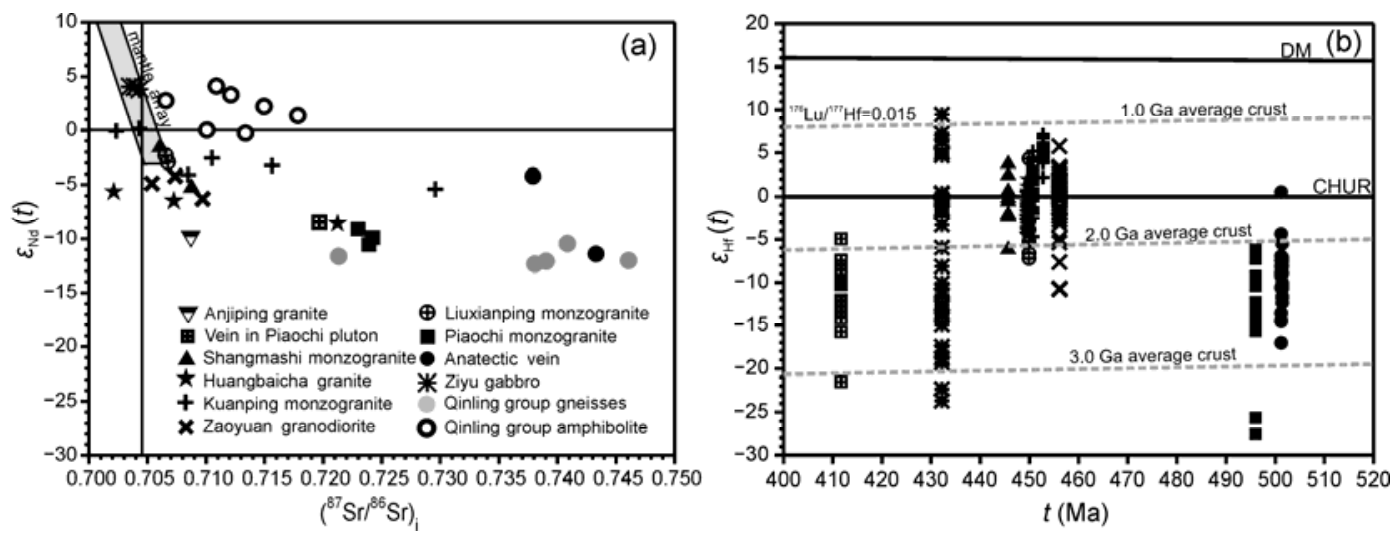

Figure 3 Plot of Sr-Nd isotopes (a) and $\varepsilon_{\mathrm{Hf}}(t)$ values corrected to the crystallization ages of zircon (b) for the granitoids in NQB. 
decoupling between $\mathrm{Nd}$ isotope of whole rock and zircon $\mathrm{Hf}$ isotopic composition. Generally, this kind of decoupling is interpreted in two ways: (1) depleted mantle-derived magma was highly contaminated by crustal materials when it rose from mantle wedge above subduction zone, triggered by slab break-off; and (2) metasomatism within mantlewedge above subduction zone resulted from aqueous fluids derived from subducted crust [17]. In this case, fluids usually contain ancient detrital zircons, and the metasomatized peridotites are juvenal lithospheric mantle. Thus, mafic magmas generated as a result of partial melting of mantle that experienced crust-mantle reaction in subduction channel tends to be relatively depleted in $\mathrm{Sr}$ and $\mathrm{Nd}$ isotopic composition of whole rock and displays variations of depletion and enrichment of zircon Hf compositions. The Ziyu gabbros have negative to positive zircon $\varepsilon_{\mathrm{Hf}}(t)$ values, and consistent $\mathrm{Si}_{2} \mathrm{O}$, and no evident increase in LREE and LILEs, indicating that they were derived from partial melting of mantle source that have undergone crust-mantle reaction in subduction channel. Compared with the monzogranites and granitoids, the garnet-bearing granites have relatively high $\mathrm{SiO}_{2}(70.03 \%-76.75 \%), \mathrm{K}_{2} \mathrm{O}+\mathrm{Na}_{2} \mathrm{O}(7.42 \%-$ $8.85 \%), \mathrm{FeO}^{\mathrm{T}}(0.34 \%-3.05 \%)$ and low $\mathrm{MgO}(0.04 \%-1.50 \%$; $\mathrm{Mg} \#=20.57-51.98)$. The $\mathrm{Al}_{2} \mathrm{O}_{3}$ values are from $12.86 \%$ to $15.53 \%$. Thus, they are calcic-alkalic and metaluminous with $\mathrm{A} / \mathrm{CNK}$ values from 0.99 to 1.16 . They are geochemically characterized by moderate fractionation between LREE and HREE with strong to moderate $\mathrm{Eu}$ anomalies $\left(\mathrm{Eu} / \mathrm{Eu}^{*}=0.12-0.79\right)$ and enrichment of $\mathrm{Rb}$, depletion of $\mathrm{Th}$, $\mathrm{Ba}, \mathrm{Sr}$ and $\mathrm{Ti}$, thereby displaying the characteristics of S-type granitoids. They show moderate initial ${ }^{87} \mathrm{Sr} /{ }^{86} \mathrm{Sr}$ ratios from 0.70605 to 0.70855 and negative $\varepsilon_{\mathrm{Nd}}(t)$ values from -4.99 to -1.22 (Figure 3$)$. The tow-stage model ages $\left(T_{\mathrm{DM} 2}\right)$ vary from 1.59 to $1.29 \mathrm{Ga}$. The zircon $\varepsilon_{\mathrm{Hf}}(t)$ values are from -6.2 to 5.0 (Figure 3 ), and $T_{\mathrm{DM} 2}$ from 1.01 to $1.54 \mathrm{Ga}$, indicating that they were the products of the partial melting of Mesoproterozoic sedimentary rocks. In addition, the Liuxianping pluton shares geochemical features with those of adakite rocks, characterized by strong fractionation between LREE and HREE, slightly Eu anomaly and high Sr, low Y and high $\mathrm{Sr} / \mathrm{Y}$ ratios. These facts indicate that they were generated in thickened crust in a post-collisional setting. This tectonothermal event likely resulted in intrusions of the magma derived from partial melting of the crust at different depths due to the crustal uplifting and of the mantle- derived magma as a result of subducted slab break-off. Some local crust-derived magma was mixed with juvenile mantle-derived magma.

The third-stage $(\sim 420 \mathrm{Ma})$ granitic plutons are coeval with retrogressive metamorphism of amphibolite facies due to second uplifting. These plutons appear as small stocks/or veins and intrude into the Qinling Group. They are mostly undeformed massive leucogranite with high $\mathrm{SiO}_{2}(73.96 \%$ $-74.22 \%), \quad \mathrm{K}_{2} \mathrm{O}+\mathrm{Na}_{2} \mathrm{O} \quad(8.70 \%-9.0 \%), \quad \mathrm{Al}_{2} \mathrm{O}_{3} \quad\left(\mathrm{Al}_{2} \mathrm{O}_{3}=\right.$ $14.01 \%-14.43 \% ; \mathrm{A} / \mathrm{CNK}=1.07-1.17)$ and $\mathrm{FeO}^{\mathrm{T}}(0.39 \%-$
$1.21 \%)$, low $\mathrm{MgO}\left(0.10 \%-0.15 \% ; \mathrm{Mg}^{\#}=21.72-36.08\right)$, and thus belong to the peraluminous high-K calc-alkaline to shoshonitic series. Geochemically, they are characterized by the low to moderate fractionation between LREE and HREE with strongly negative Eu anomaly $\left(\mathrm{Eu} / \mathrm{Eu}^{*}=0.13-0.37\right)$ and depletion of $\mathrm{Nb}, \mathrm{Ta}, \mathrm{Sr}, \mathrm{P}$ and $\mathrm{Ti}$, showing typical features of highly differentiation granitiods. They possess high radioactive isotope with the $\left({ }^{87} \mathrm{Sr} /{ }^{86} \mathrm{Sr}\right)_{\mathrm{i}}$ ratios of 0.70882 to $0.72047, \varepsilon_{\mathrm{Nd}}(t)$ values of -17.70 to -7.65 (Figure 3 ). The $T_{\mathrm{DM} 2}$ varies from 1.97 to $1.78 \mathrm{Ga}$. Zircon $\varepsilon_{\mathrm{Hf}}(t)$ values are from -21.1 to -5.1 (Figure 3), $T_{\mathrm{DM} 2}$ from 1.46 to $2.29 \mathrm{Ga}$, suggesting that they were formed mainly by the partial melting of the Mesoproterozoic crustal materials. On account of strong differentiation and high $\mathrm{K}$ contents, the leucogranite resulted likely from high differentiation of crustderived magma in an extensional setting.

\section{Concluding remarks}

Our study demonstrates three-stages of granitic magmatism in NQB that are genetically related to the ca. 500 Ma deep continental-subduction, ca. 450 Ma crustal thickening and uplifting due to continent-continent collision, and subsequent crustal uplifting in ca. $420 \mathrm{Ma}$, respectively. The ca. $500 \mathrm{Ma}$ granitoids are the products of S-type magma generated as a result of the partial melting of sedimentary rocks of an accretion wedge between the SQB and NQB including the southern margin of the NCB during the continental collision. The ca. 450 Ma granitic magmatism resulted from the partial melting of the crust due to dehydration of deep-subducted continental materials. The crustal thickening and slab break-off during the subduction and convergence might have played an important role in the upwelling and partial melting of mantle wedge materials. It was then followed by the intrusion of mantle-derived basic magma owing to partial melting of crustal materials, and widespread occurrence of monzogranites and granodiorites in the NQB. Contractional tectonism led to shortening and dehydration of supracrustal rocks. The partial melting of supracrustal pelitic rocks then produced highly differentiated leucogranite, indicating that the NQB had switched to a stable or extensional tectonic setting around $420 \mathrm{Ma}$.

Thanks go to academician Zheng Yongfei and two anonymous reviewers for their constructive comments that led to the improvement of the paper. We are grateful to Dr. Meng Qingren for polishing the English. This work was supported by the National Key Basic Research Program of China (2009CB825003 and 2009CB825006) and MOST Special Fund from the State Key Laboratory of Continental Dynamics, Northwest University.

1 Zhang G W, Meng Q R, Lai S C. Tectonics and structure of the Qinling Orogenic belt. Sci China Ser D-Earth Sci, 1995, 38: 1379-1394

2 Zhang G W, Zhang B R, Yuan X C, et al. Qinling Orogenic Belt and Continental Dynamics (in Chinese). Beijing: Science Press, 2001. $1-855$ 
3 Meng Q R, Zhang G W. Geological framework and tectonic evolution of the Qinling orogen, Central China. Tectonophysics, 2000, 323: 183-196

$4 \mathrm{Hu} \mathrm{N} \mathrm{G,} \mathrm{Zhao} \mathrm{D} \mathrm{L,} \mathrm{Xu} \mathrm{B} \mathrm{Q,} \mathrm{et} \mathrm{al.} \mathrm{Discovery} \mathrm{and} \mathrm{significance} \mathrm{of}$ coesite eclogite in Northern Qinling Mountain (in Chinese). Chin Sci Bull (Chin Ver), 1994, 24: 2013

5 Lin L, Zhou D W. Discovery and first study of high-pressure basic granulite from Songshugou, East Qinling (in Chinese). Chin Sci Bull (Chin Ver), 1994, 39: 1599-1601

6 Liu L, Zhou D W, Dong Y P, et al. High pressure metabasites and their retrograde metamorphic $P-T-t$ path from Songshugou area, eastern Qinling Mountain (in Chinese). Acta Petrol Sin, 1995, 11: $127-136$

7 Liu L, Zhou D W, Wang Y, et al. Study and implication of the high-pressure felsic granulite in the Qinling complex of East Qinling. Sci China Ser D-Earth Sci, 1996, 39: 60-68

8 Yang J S, Xu Z Q, Pei X Z, et al. Discovery of Diamond in North Qinling: Evidence for a Giant UHPM Belt across Central China and Recgnition of Paleozoic and Mesozoic Dual Deep Subduction between North China and Yangtze Plates (in Chinese). Acta Geol Sin, 2002, 76: 484-495

9 Yang J S, Liu F L, Wu C L, et al. Two ultrahigh pressure metamorphic events recognized in the central orogenic belt of China: Evidence from the U-Pb Dating of Coesite-bearing Zircons (in Chinese). Acta Geol Sin, 2003, 77: 463-477

10 Chen D L, Liu L, Sun Y, et al. LA-ICP-MS zircon U-Pb dating for high-pressure basic granulite from North Qinling and its geological significant (in Chinese). Chin Sci Bull (Chin Ver), 2004, 49: 22962304

11 Chen D L, Liu L. New data on the chronology of eclogite and associated rock from Guanpo Area, North Qinling orogeny and its constraint on nature of North Qinling HP-UHP eclogite terrane (in Chinese). Earth Sci Front, 2011, 18:158-168

12 Zhang J X, Yu S Y, Meng F C. Ployphase Early Paleozoic metamorphism in the northern Qinling orogenic belt (in Chinese). Acta Petrol Sin, 2011, 27: 1179-1190

13 Wang $\mathrm{H}, \mathrm{Wu} \mathrm{Y} \mathrm{B}$, Gao S, et al. Eclogite origin and timings in the North Qinling terrane, and their bearing on the amalgamation of the South and North China Blocks. J Metamorph Geol, 2011, 29: 10191031

14 Cheng H, Zhang C, Vervoort J D, et al. Geochronology of the transition of eclogite to amphibolite facies metamorphism in the North Qinling orogen of central China. Lithos, 2011, 125: 969-983

15 Cheng $\mathrm{H}$, Zhang C, Vervoort J D, et al. Timing of eclogite facies metamorphism in the North Qinling by $\mathrm{U}-\mathrm{Pb}$ and $\mathrm{Lu}-\mathrm{Hf}$ geochronology. Lithos, 2012, 136-139: 46-59

16 Liu L, Liao, X Y, Zhang C L, et al. Multi-matemorphic timings of HP-UHP rocks in the North Qinling and their geological implications (in Chinese). Acta Petrol Sin, 2013, 29: 1634-1656

17 Zheng Y F. Metamorphic chemical geodynamics in continental subduction zones. Chem Geol, 2012, 328: 5-48

18 Zheng Y F, Zhang L F, Liu L, et al. progress in the study of continental deep subduction and ultrahigh pressure metamorphism (in Chinese). Bull Miner Petrol Geochem, 2013, 32: 135-158

19 Zheng Y F. A perspective view on ultrahigh-pressure metamorphism and continental collision in the Dabie-Sulu orogenic belt. Chin Sci Bull, 2008, 53: 3081-3104

20 Zhao Z F, Zheng Y F, Wei C S, et al. Origin of postcollisional magmatic rocks in the Dabie orogen: Implications for crust-mantle interaction and crustal architecture. Lithos, 2011, 126: 99-114
21 Shi Y, Yu J, Santosh M. Tectonic evolution of the Qinling orogenic belt, Central China: New evidence from geochemical, zircon U-Pb geochronology and Hf isotopes. Precambrian Res, 2013, 231: 19-60

22 Lei M. Petrogenesis of granites and their relation to tectonic evolution of orogen in the east part of Qinling orogenic belt (in Chinese). Dissertation for the Doctoral Degree. Beijing: Chinese Academy of Geological Scineces, 2010. 46-81

23 Lu S N, Chen Z H, Xiang Z Q, et al. U-Pb ages of detrital zircons from the para-metamorphic rocks of the Qinling Group and their geological significance (in Chinese). Earth Sci Front, 2006, 13: 303-310

24 Wang $\mathrm{T}$, Zhang Z Q, Wang Y B, et al. Neoproterozoic collisional deformationg in the core of the Qinling orogen and its age: Constrained by zircon SHRIMP dating of strongly deformed syn-collisional granites and weakly deformed granitic veins (in Chinese). Acta Geol Sin, 2005, 79: 220-231

25 Dong Y P, Zhang G W, Hauzenberger C, et al. Palaeozoic tectonics and evolutionary history of the Qinling orogen: Evidence from geochemistry and geochronology of ophiolite and related volcanic rocks. Lithos, 2011, 122: 39-56

26 Wang T, Wang X X, Tian W, et al. North Qinling Paleozoic granite associations and their variation in space and time: Implications for orogenic processes in the orogens of Central China. Sci China Ser D-Earth Sci, 2009, 52: 1359-1384

27 Lu S N, Li H K, Chen Z H, et al. Meso-Neoproterozoic Geological Evolution of the Qinling and Its Respondence to Rodinia Event (in Chinese). Beijing: Geological Publishing House, 2003. 1-194

28 Liu J F, Sun Y, Sun W D. LA-ICP-MS zircon dating from the Lajimiao mafic complex in the Qinling orogenic belt (in Chinese). Acta Petrol Sin, 2009, 25: 320-330

29 Liu J F, Sun Y, Li H Y, et al. LA-ICP-MS zircon dating of Sifangtai mafic-ultramafic complex in the North Qinling orogenic belt (in Chinese). Acta Petrol Miner, 2012, 31: 524-530

30 Ratschbacher L, Hacker B R, Calvert A, et al. Tectonics of the Qinling (Central China): Tectonostratigraphy, geochronology, and deformation history. Tectonophysics, 2003, 366: 1-53

31 Gao S, Zhang B R, Gu X M, et al. Silurian-Devonian provenance changes of South Qinling basins: Implications for accretion of the Yangtze (South China) to the North China cratons. Tectonophysics, 1995, 250: 183-197

32 Wu Y B, Zheng Y F. Tectonic evolution of a composite collision orogen: An overview on the Qinling-Tongbai-Hong'an-Dabie-Sulu orogenic belt in central China. Gond Res, 2013, 23: 1402-1428

33 Dong Y P, Zhang G W, Neubauer F, et al. Tectonic evolution of the Qinling orogen, China: Review and synthesis. J Asian Earth Sci, 2011, 41: 213-237

$34 \mathrm{Li} \mathrm{H} \mathrm{K,} \mathrm{Lu} \mathrm{S} \mathrm{N,} \mathrm{Chen} \mathrm{Z} \mathrm{H,} \mathrm{et} \mathrm{al.} \mathrm{Zircon} \mathrm{U-Pb} \mathrm{geochronology} \mathrm{of} \mathrm{rift-}$ type volcanic rocks of the Yaolinghe Group in the South Qinling orogen (in Chinese). Geol Bull Chin, 2003, 22: 775-781

35 Ling W L, Ren B F, Duan R C, et al. Timing of the Wudangshan, Yaolinghe volcanic sequences and mafic sills in South Qinling: U-Pb zircon geochronology and tectonic implication. Chin Sci Bull, 2008, 53: 2193-2206

36 Xiao L, Zhang H F, Ni P Z, et al. LA-ICP-MS U-Pb zircon geochronology of early Neoproterozoic mafic-intermediate intrusions from NW margin of the Yangtze Block, South China: Implication for tectonic evolution. Precambrian Res, 2007, 54: 221-235

37 Zhao J H, Zhou M F, Zheng J P, et al. Neoproterozoic crustal growth and reworking of the Northwestern Yangtze Block: Constraints from the Xixiang dioritic intrusion, South China. Lithos, 2010, 120: 439452

Open Access This article is distributed under the terms of the Creative Commons Attribution License which permits any use, distribution, and reproduction in any medium, provided the original author(s) and source are credited. 